\title{
Nitrogen isotope fractionation during nitrate, ammonium and urea uptake by marine diatoms and coccolithophores under various conditions of $\mathbf{N}$ availability
}

\author{
Nathalie A. Waser ${ }^{1, *}$, Kedong Yin ${ }^{1}$, Zhiming Yu ${ }^{2}$, Kuninao Tada ${ }^{3}$, Paul J. Harrison ${ }^{1}$, \\ David H. Turpin ${ }^{4}$, Stephen E. Calvert ${ }^{1}$ \\ ${ }^{1}$ Department of Earth and Ocean Sciences, University of British Columbia, Vancouver, British Columbia V6T 1Z4, Canada \\ ${ }^{2}$ Institute of Oceanology, Chinese Academy of Sciences, Qingdao, Shandong 266071, China \\ ${ }^{3}$ Department of Bioresource Science, Faculty of Agriculture, Miki, Kagawa 761-07, Japan \\ ${ }^{4}$ Department of Biology, Queen's University, Kingston, Ontario K7L 3N6, Canada
}

\begin{abstract}
Stable isotopes of $\mathrm{N}$ provide a new approach to the study of algal production in the ocean, yet knowledge of the isotope fractionation $\{\varepsilon$, in various oceanic regimes is lacking. Here we report large and rapid changes in isotope composition $\left(\delta^{15} \mathrm{~N}\right)$ of 2 coastal diatoms and 2 clones (open and coastal) of a coccolithophore grown in the simultaneous presence of nitrate, ammonium and urea under varying conditions of $\mathrm{N}$ availability (i.e. $\mathrm{N}$-sufficiency and $\mathrm{N}$-starvation followed by $\mathrm{N}$-resupply) and hence different physiological states. During $\mathrm{N}$-sufficiency, the $\delta^{15} \mathrm{~N}$ of particulate organic $\mathrm{N}$ (PON) was well reproduced, using a model derived from Rayleigh distillation theory, with constant $\varepsilon$ similar to that for growth on each individual $\mathrm{N}$ source. However, following $\mathrm{N}$-resupply, the variations in $\delta^{15} \mathrm{~N}_{\text {pon }}$ could be well explained only in the case of the open ocean Emiliania huxleyi, with $\varepsilon$ similar to $\mathrm{N}$-sufficient conditions. It was concluded that the mechanism of isotope fractionation changed rapidly with $\mathrm{N}$ avail ability for the 3 coastal clones. However, in the case of $E$. huxley isolated from the Subarctic Pacific Ocean, no evidence of a change in mechanism was found, suggesting that perhaps open ocean species can quickly recover from $\mathrm{N}$-depleted conditions
\end{abstract}

KEY WORDS: Isotope fractionation $\cdot{ }^{15} \mathrm{~N} /{ }^{14} \mathrm{~N} \cdot$ Nitrogen uptake Diatoms Coccolithophores Nitrate Ammonium - Urea

\section{INTRODUCTION}

The incorporation of nitrogen is a key factor limiting phytoplankton production in the ocean. Furthermore, the form of $\mathrm{N}$ incorporated determines the partitioning between new and regenerated production. The use of natural stable isotopes of $\mathrm{N}$ has provided new ways with which to examine the relationships between $\mathrm{N}$ sources and primary production. In principle, during growth on a particular $\mathrm{N}$ source, phytoplankton discriminate between ${ }^{14} \mathrm{~N}$ and ${ }^{15} \mathrm{~N}$ and preferentially

·E-mail: nwaser@unixg.ubc.ca incorporate ${ }^{1 /} \mathrm{N}$. Knowledge of the fact that isotope fractionation $(\varepsilon)$ varies with source should provide an important tool for distinguishing between new and regenerated production (Wada \& Hattori 1978, Montoya \& McCarthy 1995, Pennock et al. 1996, Waser et al. 1998). Yet, further use of $N$ isotope ratios is hindered by the lack of knowledge of $\varepsilon$ in various oceanic regimes which can differ in terms of $\mathrm{N}$ availability (i.e. $\mathrm{N}$-sufficient and $\mathrm{N}$-depleted) and thus physiological state, $N$ source (nitrate, ammonium and urea) and species composition.

In eutrophic oceanic regions, evidence for isotope fractionation of 4 to $5 \%$ has been obtained where productivity is nitrate-based (Wada 1980, Horrigan et al. 
1990, Altabet et al. 1991, Sigman et al. 1996, Voss et al. 1996. Wu et al. 1997). These field estimates are supported by estimates of 2 to $12 \%$ determined in cultures (Montoya \& McCarthy 1995, Pennock et al. 1996, Needoba 1997, Waser et al. 1998). In coastal environments, phytoplankton growth on ammonium is accompanied by an isotope fractionation of 6.5 to $9 \%$ (Cifuentes et al. 1989. Montoya et al. 1991). This is lower than the recent estimates of 20 to $26 \%$ for growth of diatoms on levels of $\mathrm{NH}_{4}^{+}$of more than $20 \mu \mathrm{M}$ (Pennock et al. 1996. Waser et al. 1998) but similar to the 5 to $10 \%$ obtained during growth on $20 \mu \mathrm{M} \mathrm{NH}_{4}{ }^{+}$(Pennock et al. 1996). The discrepancy between culture and field estimates may therefore be due to a concentration effect (Hoch et al. 1992, Pennock et al. 1996). Unlike growth on nitrate and ammonium, isotope fractionation during growth on urea is very small and around $0.7 \%$ (Waser et al. 1998).

Less is known about fractionation in oligotrophic regimes. Typically, the $\delta^{15} \mathrm{~N}$ of particulate organic $\mathrm{N}$ $\left(\delta^{15} N_{P O N}\right)$ is lower and exhibits much smaller variations relative to eutrophic regions (Altabet 1988, Villareal et al. 1993). There are no estimates of $\varepsilon$ in those environments because of the extremely low ambient nutrient concentrations. However, it has been hypothesized that because dissolved $\mathrm{N}$ is in such low concentration, $\varepsilon$ may be as low as $0 \%$, signifying that all $\mathrm{N}$ taken up by the cell is assimilated (Fogel \& Cifuentes 1993). This change may come about due to a decrease in the efflux of $N$ out of the cell (Mariotti et al. 1982, Handley \& Raven 1992, Evans et al. 1996) and in extremely $\mathrm{N}$-depleted environments one may hypothesize that $\mathrm{N}$ efflux may be close to zero.

In a previous study (Waser et al. 1998), we determined $\varepsilon$ associated with the uptake of the 3 most important $\mathrm{N}$ sources for phytoplankton, $\mathrm{NO}_{3}{ }^{-}, \mathrm{NH}_{4}{ }^{+}$ and urea (McCarthy \& Goldman 1979, Harrison 1992). In this paper, we are investigating the variations in $\delta^{15} \mathrm{~N}_{\text {PON }}$ during phytoplankton growth on these $\mathrm{N}$ sources when they are all present simultaneously. To this end, ecologically important species of coccolithophores and diatoms were grown in pure cultures in the laboratory. Growth conditions were designed to simulate eutrophic and oligotrophic and/or temporarily $\mathrm{N}$-depleted surface oceans. To this end, the algae were grown under $\mathrm{N}$-sufficient and $\mathrm{N}$-depleted conditions (i.e. $N$-starvation followed by the resupply of all 3 $\mathrm{N}$ sources). The $\mathrm{N}$-sufficient phase was designed to simulate bloom conditions and coastal environments where the concentration of dissolved $\mathrm{N}$ is large relative to its biological uptake. In contrast, the N-resupply phase simulated oligotrophic oceans where new and regenerated $N$ are supplied to the $N$-depleted surface ocean during episodic events. Variations in $\mathrm{N}$ availability were expected to produce changes in $\varepsilon$ and, in particular, we hypothesized that in the $\mathrm{N}$-resupply phase following $\mathrm{N}$-starvation $\varepsilon$ might be significantly reduced relative to the $\mathrm{N}$-sufficient phase.

\section{MATERIALS AND METHODS}

Cultures. Two coastal diatoms, Thalassiosira pseudonana (NPCC 58) and Chaetoceros debilis (NPCC 644), and 2 clones of the coccolithophore Emiliania huxleyi (NPCC 646 and NPCC 732) were obtained from the Northeast Pacific Culture Collection (NPCC), Department of Earth and Ocean Sciences, University of British Columbia. E. huxleyi (NPCC 732) is an open ocean clone isolated from Stn Papa located in the Northeast Subarctic Pacific gyre and has coccoliths, while the other clone of E. huxleyi (NPCC 646) is noncalcifying (i.e. naked) and is a coastal clone. All culture experiments were performed in triplicate. However, in the case of $C$. debilis one culture did not grow. The cultures were grown on artificial seawater (ESAW) following a modified recipe of Harrison et al. (1980). They were grown on $3 \mathrm{~N}$ sources present simultaneously, i.e. $\mathrm{NO}_{3}{ }^{-}, \mathrm{NH}_{4}{ }^{+}$and $\mathrm{CO}\left(\mathrm{NH}_{2}\right)_{2}$, in batch cultures, at $18 \pm$ $0.5^{\circ} \mathrm{C}$, in continuous light $\left(120 \mu \mathrm{mol}\right.$ photons $\left.\mathrm{m}^{-2} \mathrm{~s}^{-1}\right)$ as described in detail elsewhere (Waser et al. 1998). The batch culture inoculum had been acclimated to the same medium for 8 to 10 generations. After inoculation, the cultures were grown first in N-sufficient conditions. They were then $\mathrm{N}$-starved for 40 to $60 \mathrm{~h}$, and then all three $\mathrm{N}$ sources were resupplied to the medium. The total concentration of $\mathrm{NO}_{3}{ }^{-}, \mathrm{NH}_{4}{ }^{+}$and $\mathrm{CO}\left(\mathrm{NH}_{2}\right)_{2}$ was 100 to $130 \mu \mathrm{M}$ in the $\mathrm{N}$-sufficient phase and ranged from 50 to $130 \mu \mathrm{M}$ in the $N$-resupply phase. In one culture of the coastal clone of E. huxleyi, urea concentration was $73 \mu \mathrm{M}$ in the $\mathrm{N}$-sufficient phase and thus double the concentration of $\mathrm{NO}_{3}{ }^{-}$and $\mathrm{NH}_{4}{ }^{+}$. However, 2 duplicate cultures of the coastal clone of E. huxleyi were grown with 30 to $35 \mu \mathrm{M}$ of urea and showed similar results. The N:P and Si:N ratios in the medium were $4: 1$ and $2: 1$, respectively, to ensure that $\mathrm{N}$ was limiting biomass at the stationary phase. Bicarbonate $\left(\mathrm{NaHCO}_{3}\right)$ was initially $2 \mathrm{mM}$ and $0.9 \mathrm{~g}$ was added daily to the $6 \mathrm{l}$ cultures to prevent C-limitation. Each addition was accompanied by a small decrease in $\mathrm{pH}$. The $\mathrm{pH}$ increased from 8.0-8.2 to 8.5-8.9 during log phase grawth in $\mathrm{N}$-sufficient conditions and remained fairly constant following $\mathrm{N}$-resupply. Both the inoculum and the experimental culture of the calcifying coccolithophore were grown on ESAW, although this clone is grown in the culture collection on surface seawater collected at Stn Papa to allow the coccoliths to be maintained. Calcifying cells constituted about $50 \%$ of the experimental. triplicate cultures. 
Biomass, PON and nutrient analysis. Samples for nutrients, particulate matter, fluorescence and cell density were collected at time intervals ranging up to $120 \mathrm{~h}$. PON samples were collected by vacuum filtration at 0.5 atm on pre-combusted $\left(450^{\circ} \mathrm{C}\right)$ glass-fiber filters (GF/F) and determinations were made on a Fisons automated CHN analyzer on-line with a mass spectrometer. The precision of each PON analysis was 1 to $2 \%$. The filtrate was used for nitrate, ammonium and urea analyses which were determined manually and with a Technicon Autoanalyzer. Manual nitrate analyses were made using a spongy cadmium method (Jones 1984) slightly modified for small volumes (D. Bronk, University of Georgia at Athens, pers. comm.j. Ammonium was analyzed according to Slawyk \& Maclsaac (1972) and urea according to the diacetyl monoxime method described by Price \& Harrison (1987).

Nitrogen isotope analysis. Isotopic abundance was determined with a VG PRISM dual inlet, triple collector mass spectrometer operated in continuous flow mode. Results are reported in the delta notation (\%o):

$$
\delta^{15} \mathrm{~N}=\left(\frac{R_{\text {sample }}}{R_{\text {standard }}}-1\right) \times 1000
$$

where $R$ is the ${ }^{15} \mathrm{~N} /{ }^{14} \mathrm{~N}$ ratio and the standard is atmospheric air $(0 \%)$. Routinely, a standard of acetanilide is run frequently (every 5 to 10 samples). The precision is $0.17 \%$.

Multiple $\mathbf{N}$ source uptake model. A model was developed for simulating the $\delta^{15} N_{\text {PON }}$ which results from growth on multiple $N$ sources. The model does not address the mechanism of isotope fractionation, but tests whether $\delta^{15} \mathrm{~N}_{\text {PON }}$ can be described as the weighted sum of the changes in $\delta^{15} N_{\text {PON }}$ which would result from the incorporation of each individual $N$ source, assuming that they follow the accumulation product equation (Mariotti et al. 1981). Thus each $N$ incorporation is treated as a unidirectional reaction $\left(\mathrm{NO}_{3}{ }^{-} \rightarrow\right.$ PON, $\mathrm{NH}_{4}{ }^{+} \rightarrow \mathrm{PON}$, urea $\rightarrow$ PON) and the total $\mathrm{N}$ incorporation is described as the sum of these reactions. $\varepsilon$ has been previously determined for Thalassiosira pseudonana when each of these sources was the sole source of $N$ (Waser et al. 1998). The model uses this information and evaluates whether it can be used in a more complex situation where all $3 \mathrm{~N}$ sources are present simultaneously. It further assumes that there is an isotope mass balance (i.e. no loss and no other $N$ form involved except $\mathrm{NO}_{3}{ }^{-}, \mathrm{NH}_{4}{ }^{+}$, urea and $\left.\mathrm{PON}\right)$. The $\delta^{15} \mathrm{~N}_{\text {PON }}\left(\delta^{15} \mathrm{~N}_{\mathrm{x}}\right)$ for growth on a source $\mathrm{x}$ is given by the accumulated product equation as in our previous study:

$$
\delta^{15} N_{x}=\delta^{15} N_{x s}-\varepsilon_{x} \cdot F_{x}
$$

where $\mathrm{x}$ is $\mathrm{NO}_{3}{ }^{-}, \mathrm{NH}_{4}{ }^{+}$or urea, $\delta^{15} \mathrm{~N}_{\mathrm{xs}}$ is the $\delta^{15} \mathrm{~N}$ of the initial source, $\varepsilon_{x}$ is the isotope fractionation during the incorporation of $\mathrm{x}$ and $F_{\mathrm{x}}=-\left[f_{\mathrm{x}} /\left(1-f_{\mathrm{x}}\right)\right] \ln f_{\mathrm{x}}$, where $f_{\mathrm{x}}$ is the fraction of unconsumed $N$ source. The variables are given in Table $1 . \delta^{15} \mathrm{~N}_{\mathrm{PON}}$ is then as follows:

$$
\delta^{15} N_{\text {PON }}=\sum_{x} \frac{\mathrm{PON}_{x} \cdot \delta^{15} N_{x}}{\sum \operatorname{PON}_{x}}
$$

where PON $\mathrm{P}_{\mathrm{x}}$ is the PON that is produced from growth on a source $x . P O N_{x}$ is calculated from the changes in $\mathrm{N}$ source concentration (i.e. $\left[\mathrm{NO}_{3}{ }^{-}\right],\left[\mathrm{NH}_{4}{ }^{+}\right]$and [urea]). The time-dependent expressions for $\left[\mathrm{NO}_{3}{ }^{-}\right], \quad\left[\mathrm{NH}_{4}{ }^{+}\right]$ and [urea] are determined by the fits of the dissolved $\mathrm{N}$ data. In the N-resupply phase a large amount of PON was present prior to $\mathrm{N}$-addition and the appropriate correction for initial concentration of PON $\left(\mathrm{PON}_{1}\right)$ was made. In the $\mathrm{N}$-sufficient phase, a small correction was also made to account for the PON that was carried over

\begin{tabular}{|c|c|c|c|}
\hline Variable & Definition & Value $^{a}$ & Unit \\
\hline $\mathrm{PON}_{\mathrm{m}}$ & Measured PON concentration & & $\mu \mathrm{M}$ \\
\hline$\sum \mathrm{PON}_{\mathrm{x}}$ & Calculated PON concentration from dissolved $\mathrm{N}$ drawdown & & $\mu \mathrm{M}$ \\
\hline $\mathrm{PON}_{1}$ & Initial PON concentration & & $\mu \mathrm{M}$ \\
\hline$\delta^{15} \mathrm{~N}_{\mathrm{ns}}$ & $\delta^{15} \mathrm{~N}$ of the initial nitrate source & 3.04 & $\%$ \\
\hline$\delta^{15} \mathrm{~N}_{\mathrm{ac}}$ & $\delta^{15} \mathrm{~N}$ of the initial ammonium source & -1.14 & $\%$ \\
\hline$\delta^{15} \mathrm{~N}_{\text {us }}$ & $\delta^{15} \mathrm{~N}$ of the initial urea source & -0.74 & $\%$ \\
\hline$\delta^{15} \mathrm{~N}_{\mathrm{mx}}$ & $\delta^{15} \mathrm{~N}$ of the initial mixed $\mathrm{N}$ sources (calculated from mass balance) & $0.12-0.57$ & $\%$ \\
\hline$\delta^{15} \mathrm{~N}_{\mathrm{st}}$ & $\delta^{15} \mathrm{~N}$ of PON at stationary phase & & $\%$ \\
\hline$\delta^{15} \mathrm{~N}_{\mathrm{PON}_{1}}$ & $\delta^{15} \mathrm{~N}$ of $\mathrm{PON}_{1}$ & & $\%$ \\
\hline$\varepsilon\left(\mathrm{NO}_{3}\right)^{-1}$ & Isotope fractionation for the overall reaction $\mathrm{NO}_{3} \rightarrow \mathrm{PON}$ & & $\%$ \\
\hline$\varepsilon\left(\mathrm{NH}_{4}\right)$ & Isotope fractionation for the overall reaction $\mathrm{NH}_{4}{ }^{+} \rightarrow \mathrm{PON}$ & & $\%$ \\
\hline$\varepsilon($ urea) & Isotope fractionation for the overall reaction Urea $\rightarrow$ PON & 0 & $\%$ \\
\hline$\Delta$ & Apparent isotope fractionation or discrimination, i.e. $\delta^{15} N_{P O N}-\delta^{15} N_{\mathrm{si}}$ & & $\%$ \\
\hline
\end{tabular}
from the inoculum. PON $\mathrm{N}_{\mathrm{i}}$ was calculated as the differ-

Table 1. Listing of variables and definitions used in the multiple $\mathrm{N}$ source uptake model 
ence between $\sum P O N_{x}$ and the measured PON $\left(P O N_{m}\right)$. The $\delta^{15} \mathrm{~N}_{\text {pON }}$ is then as follows:

$$
\delta^{15} N_{\text {PON }}=\frac{\delta^{15} N_{\text {PON }} \cdot \sum P O N_{x}+\delta^{15} N_{\text {PON }} \cdot P O N_{i}}{\sum P O N_{x}+P O N_{i}}
$$

\section{RESULTS}

\section{Coastal clone of Emiliania huxleyi}

In the $\mathrm{N}$-sufficient phase (0 to $147 \mathrm{~h}$ ), the three $\mathrm{N}$ sources were utilized in sequence (Fig. 1A). $\mathrm{NO}_{3}^{-}$was taken up only when $\left[\mathrm{NH}_{4}^{+}\right]$decreased below detection limit, consistent with studies demonstrating inhibition of $\mathrm{NO}_{3}{ }^{-}$uptake by $\mathrm{NH}_{4}{ }^{+}$(Dortch \& Conway 1984, Dortch et al. 1991). Similarly, urea uptake began when $\left[\mathrm{NO}_{3}{ }^{-}\right]$decreased below the detection limit. During growth on $\mathrm{NH}_{4}{ }^{+}$, the apparent isotope discrimination (i.e. $\Delta$, difference between $\delta^{15} N_{\text {PON }}$ at any time and at stationary phase) was very large and decreased to a small value upon exhaustion of $\mathrm{NH}_{4}{ }^{+}$(Fig. 1B). At this time ( $88 \mathrm{~h}$ ) $\mathrm{NH}_{4}{ }^{+}$had been incorporated into PON and $\delta^{1 \cdot} \mathrm{N}_{\mathrm{PON}}$ was in good agreement with the expected value of $-1.14 \%$ (i.e. $\delta^{15} \mathrm{~N}_{\mathrm{as}}$ ). $\mathrm{NO}_{3}{ }^{-}$uptake was accompanied by a small $\Delta$ due to both a smaller $\varepsilon\left(\mathrm{NO}_{3}\right)$ and a significant amount of preexisting PON produced during growth on $\mathrm{NH}_{4}{ }^{+}$. In the 112 to $147 \mathrm{~h}$ time period, $\delta^{15} N_{\text {PON }}$ showed a slight decrease due to the uptake of urea, whose initial source had a lower $\delta^{15} \mathrm{~N}$ than nitrate (Table 1). At the stationary phase, the $\delta^{15} N_{\text {pon }}$ value of $0.2 \%$ was in good agreement with the $\delta^{15} \mathrm{~N}_{\mathrm{mx}}$ of $0.12 \%$ as expected when all 3 uptake reactions go to completion. The model gave a good fit for $\varepsilon\left(\mathrm{NH}_{4}\right), \varepsilon\left(\mathrm{NO}_{3}\right)$ and $\varepsilon$ (urea) values of 16,4 and $0 \%$, respectively, in good agreement with $\varepsilon$ previously determined for Thalassiosira pseudonana grown on single $N$ sources (Waser et al. 1998). All the base variables are summarized in Table 2 .

In the $N$-resupply phase, the reduced $N$ sources were immediately utilized, and $\mathrm{NO}_{3}{ }^{-}$uptake accelerated following the complete consumption of $\mathrm{NH}_{4}{ }^{+}$.
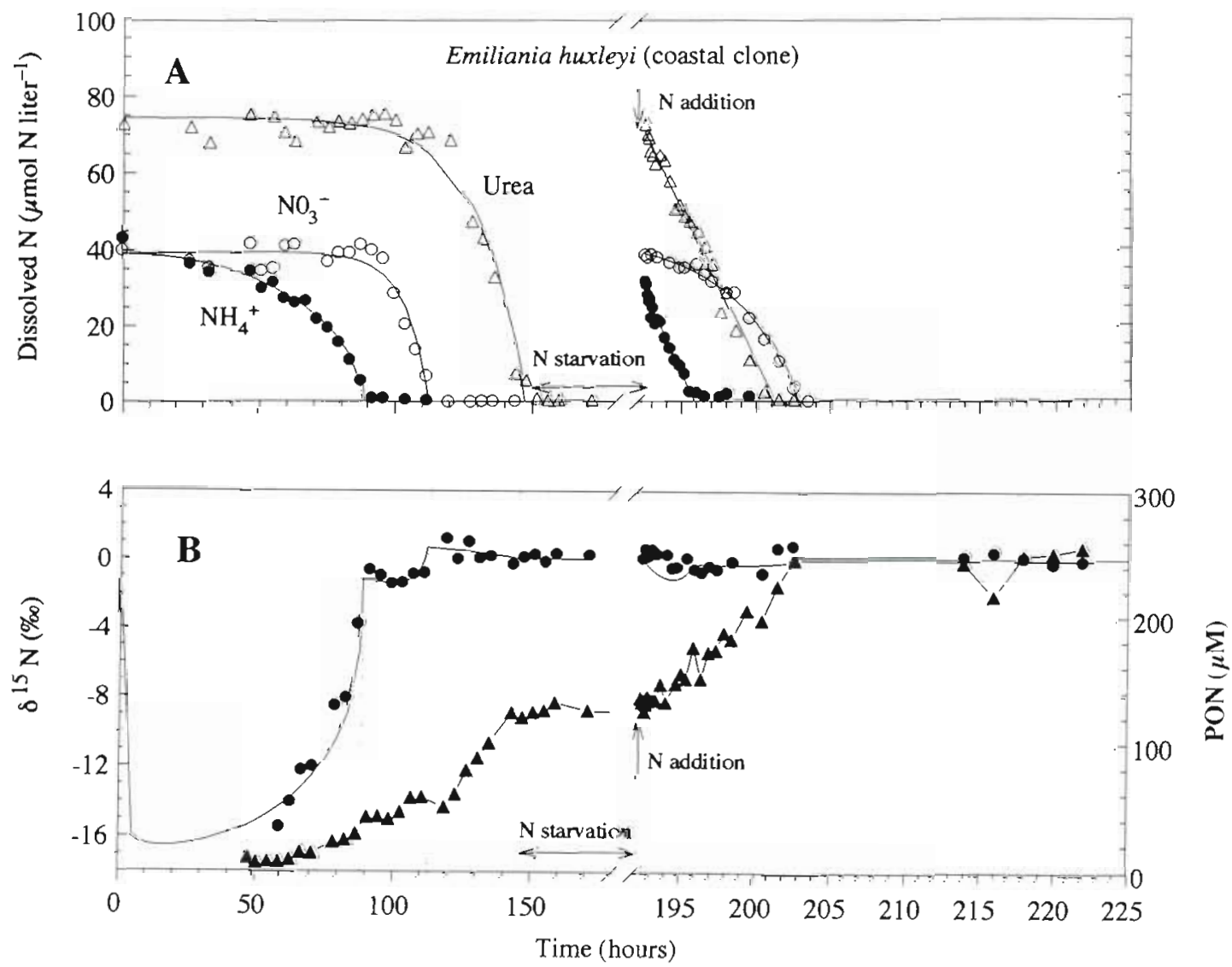

Fig. 1. Emiliania huxleyi (coastal clone). Growth on $\mathrm{NO}_{3} ; \mathrm{NH}_{4}{ }^{+}$and urea. (A) Time series of $\left[\mathrm{NO}_{3}{ }^{-}\right](\mathrm{O}),\left(\mathrm{NH}_{4}{ }^{+}\right](\bullet)$ and $[\mathrm{urea}](\Delta)$. The best fits for the concentrations are indicated by the solid lines. (B) Time series of measured PON (4) and $\delta^{15} N_{p O N}(\bullet)$. The $\delta^{15} \mathrm{~N}_{\text {PON }}$ as predicted by the multiple $\mathrm{N}$ source uptake model is shown by the solid line. The 3 dotted lines indicate tumes when $\left[\mathrm{NH}_{4}{ }^{+}\right],\left[\mathrm{NO}_{3}{ }^{-}\right]$and [urea] fits reached 0 , respectively 
Table 2. Variables and their values used in the multiple $N$ source uptake model. Three coastal phytoplankters and one open ocean species were grown on multiple N sources (nitrate, ammonium and urea) under $\mathrm{N}$-sufficient conditions. After 40 to $60 \mathrm{~h}$ of starvation all three $\mathrm{N}$ sources were added simultaneously to the culture (i.e. $\mathrm{N}$-resupply phase)

\begin{tabular}{|c|c|c|c|c|c|c|}
\hline Species & & $\begin{array}{c}\varepsilon\left(\mathrm{NH}_{4}\right) \\
(\%)\end{array}$ & $\begin{array}{c}\varepsilon\left(\mathrm{NO}_{3}\right) \\
(\%)\end{array}$ & $\begin{array}{l}\mathrm{PON}_{1} \\
(\mu \mathrm{M})\end{array}$ & $\begin{array}{c}\delta^{15} \mathrm{~N}_{\mathrm{st}}{ }^{\mathrm{a}} \\
(\%)\end{array}$ & $\begin{array}{c}\delta^{15} \mathrm{~N}_{\mathrm{mix}}{ }^{\mathrm{b}} \\
(\% \mathrm{or})\end{array}$ \\
\hline \multicolumn{7}{|l|}{$\mathrm{N}$-sufficient phase } \\
\hline Emiliania huxleyi (coastal) & & 16 & 4 & $0 \pm 1$ & 0.20 & 0.12 \\
\hline \multirow[t]{3}{*}{ Emiliania huxleyi (open ocean) } & $\mathrm{E} 1^{\mathrm{C}}$ & 19 & 4 & $3 \pm 2$ & 0.75 & 0.32 \\
\hline & $\mathrm{E} 2$ & 15 & 4 & $3 \pm 2$ & 0.70 & 0.25 \\
\hline & E3 & 18 & 4 & $5 \pm 3$ & 0.93 & 0.30 \\
\hline Thalassiosira pseudonana & & 20 & 5 & $6 \pm 2$ & 1.30 & 0.57 \\
\hline \multirow[t]{2}{*}{ Chaetoceros debilis } & $\mathrm{C} 1^{\mathrm{d}}$ & 25 & 5 & $6 \pm 2$ & 0.35 & 0.50 \\
\hline & $\mathrm{C} 2$ & 25 & 5 & $6 \pm 3$ & 0.72 & 0.50 \\
\hline \multicolumn{7}{|l|}{ N-resupply phase } \\
\hline Emiliania huxleyi (coastal) & & 16 & 4 & $134 \pm 4$ & 0.2 & 0.10 \\
\hline Emiliania huxleyi (open ocean) & E1 ${ }^{\circ}$ & 19 & 4 & $91 \pm 8$ & 1.2 & 0.45 \\
\hline Thalassiosira pseudonana & & 20 & 5 & $94 \pm 9$ & 1.2 & 1.10 \\
\hline Chaetoceros debilis & $\mathrm{C} 1^{\mathrm{d}}$ & 25 & 5 & $92 \pm 11$ & 1.5 & 0.40 \\
\hline \multicolumn{7}{|l|}{${ }^{1} \delta^{15} \mathrm{~N}$ of $\mathrm{PON}$ at stationary phase } \\
\hline \multicolumn{7}{|l|}{${ }^{1} \delta^{15} \mathrm{~N}$ of the initial mixed $\mathrm{N}$ sources } \\
\hline \multicolumn{7}{|l|}{ "Culture shown in Figs. $2 \& 6$} \\
\hline${ }^{d}$ Culture shown in Figs. $4 \& 8$ & & & & & & \\
\hline
\end{tabular}

Using the same variables as in the $\mathrm{N}$-sufficient phase, the model systematically underestimated $\delta^{15} \mathrm{~N}_{\text {PON }}$ during $\left[\mathrm{NH}_{4}{ }^{+}\right]$drawdown. A sensitivity study is presented later.

\section{Open ocean clone of Emiliania huxleyi}

In the $\mathrm{N}$-sufficient phase ( 0 to $66 \mathrm{~h}$ ), both $\mathrm{NH}_{4}{ }^{*}$ and urea were taken up first and simultaneously (Fig. 2A). $\mathrm{NO}_{3}{ }^{-}$was utilized last and only after the $\left[\mathrm{NH}_{4}{ }^{+}\right]$ decreased to below the detection limit. A similar pattern was observed for the 2 other triplicate cultures. The $\delta^{15} \mathrm{~N}_{\text {pon }}$ showed a pattern similar to the previous clone, with low initial $\delta^{15} \mathrm{~N}$ pon values of $-10 \%$, increasing to $-0.82 \%$ slightly after the complete consumption of $\mathrm{NH}_{4}{ }^{+}$(Fig. 2B). At the stationary phase, the $\delta^{15} \mathrm{~N}_{\text {PON }}$ was $0.75 \%$, a little higher than the value of $0.32 \%$ for $\delta^{15} \mathrm{~N}_{\mathrm{mx}}$. The model gave a relatively good fit for this culture as well as for the other triplicates (Table 2). The initial $\triangle$ was lower, in part due to the initial amount of PON (Table 2), but also because of the simultaneous uptake of urea and $\mathrm{NH}_{4}{ }^{+}$. This latter point is demonstrated by the good fit using the following variables: $\varepsilon$ (urea) $=0 \%$ and $\varepsilon\left(\mathrm{NH}_{4}\right)=18 \%$ (Fig. 2B). Similar results were found in all the triplicate cultures (Table 2).

In the $\mathrm{N}$-resupply phase, again the reduced $\mathrm{N}$ sources, ammonium and urea, were used first (Fig. 2A). The $\delta^{15} \mathrm{~N}_{\text {PON }}$ showed a relatively large decrease which was well predicted by the model using the same vari- ables as in the $\mathrm{N}$-sufficient phase (Table 2). These rosults suggested that the $60 \mathrm{~h}$ of $\mathrm{N}$-starvation did not affect isotope fractionation. This result shows that the cells were able to rapidly recover from $\mathrm{N}$-starvation and to respond in a similar way as in the $\mathrm{N}$-sufficient phase.

\section{Thalassiosira pseudonana}

In the $\mathrm{N}$-sufficient phase $(0$ to $47 \mathrm{~h}), \mathrm{NH}_{4}{ }^{+}$was utilized first, followed by the simultaneous uptake of $\mathrm{NO}_{3}{ }^{-}$and urea (Fig. 3A). Growth on $\mathrm{NH}_{4}{ }^{+}$produced a large initial decrease in $\delta^{15} N_{P O N}$ to values of -10 to $-12 \%$ (Fig. 3B). $\delta^{15} \mathrm{~N}_{\text {PON }}$ then increased to about $0 \%$ during the simultaneous growth on urea and $\mathrm{NO}_{3}^{-}(29$ to $47 \mathrm{~h}$ ) and finally reached an average value of $1.3 \%$ at the stationary phase. The model gave a relatively good fit for the $\mathrm{NH}_{4}{ }^{+}$uptake phase with the known $\varepsilon\left(\mathrm{NH}_{4}\right)$ value of $20 \%$ (Waser et al. 1998). However, the model systematically underestimated $\delta^{15} \mathrm{~N}_{\mathrm{PON}}$ during the simultaneous growth on urea and $\mathrm{NO}_{3}{ }^{-}$, in spite of the fact that $\varepsilon\left(\mathrm{NO}_{3}\right)$ and $\varepsilon$ (urea) are known for this species (Waser et al. 1998) $\delta^{15} N_{\mathrm{st}}$ of $1.3 \%$ was a little higher than the $\delta^{15} \mathrm{~N}_{\mathrm{mx}}$ of $0.56 \%$ (Table 2). $\delta^{15} \mathrm{~N}_{\mathrm{mx}}$ was then recalculated, making all the appropriate corrections for carryover of dissolved $\mathrm{N}$ and $\mathrm{PON}$ from the inoculum into the culture medium. The inoculum introduced: (1) $0.5 \mu \mathrm{M}$ of $\mathrm{NO}_{3}^{-}$with a $\delta^{15} \mathrm{~N}$ estimated at $10.5 \%$, (2) $0.9 \mu \mathrm{M}$ of urea with a $\delta^{15} \mathrm{~N}$ of about $-0.4 \%$ and (3) $6 \mu \mathrm{M}$ of PON with a $\delta^{15} \mathrm{~N}$ of $0 \%$. This allowed a 

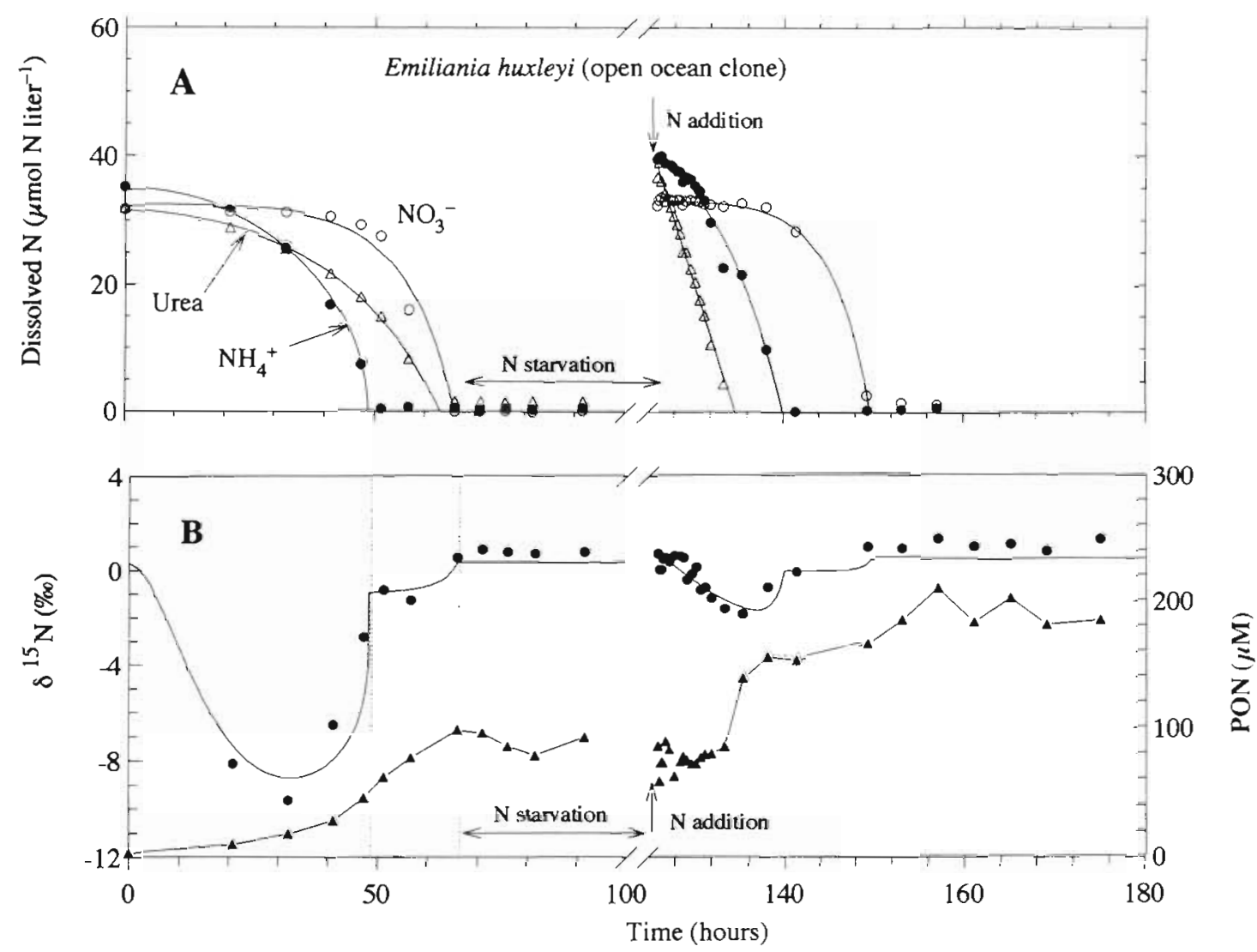

Fig. 2. Emiliania huxleyi (open ocean clone]. Growth on $\mathrm{NO}_{3}{ }^{-}, \mathrm{NH}_{4}{ }^{+}$and urea. (A) Time series of $\left[\mathrm{NO}_{3}{ }^{-}\right]\left(\mathrm{O}_{1}\right),\left[\mathrm{NH}_{4}{ }^{+}\right](\bullet)$ and $[\mathrm{urea}]$ $(\Delta)$. The best fits for the concentrations are indicated by the solid lines. (B) Time series of measured PON $(\Delta)$ and $\delta^{15} N_{P O N}(\bullet)$. The $\delta^{15} \mathrm{~N}_{\text {PON }}$ as predicted by the model is shown by the solid line. The 2 dotted lines represent times when $\left[\mathrm{NH}_{4}^{+}\right]$and $\left[\mathrm{NO}_{3}{ }^{-}\right]$fits reached 0 , respectively

value of $0.61 \%$ for $\delta^{15} \mathrm{~N}_{\mathrm{mx}}$ to be recalculated. The discrepancy between $\delta^{15} \mathrm{~N}_{\mathrm{st}}$ and $\delta^{15} \mathrm{~N}_{\mathrm{mx}}$ was probably due the excretion of a ${ }^{15} \mathrm{~N}$-depleted $\mathrm{N}$ compound. A similar effect of up to $1.4 \%$ was found for Thalassiosira pseudonana grown on $\mathrm{NO}_{3}{ }^{-}$(Waser et al. 1998). In the modeled $\delta^{15} \mathrm{~N}_{\text {PON }}$ presented in Fig. $3 \mathrm{~B}$, this effect was taken into account by using a $\delta^{15} \mathrm{~N}_{\mathrm{ns}}=4.4 \%$ instead of $3 \%$. More details are presented in the sensitivity analysis below. Following $\mathrm{N}$-resupply, both reduced $\mathrm{N}$ forms were used immediately as in the previous cultures (Fig. 3A). $\Delta$ was essentially positive, suggesting that reversed discrimination was occurring, i.e. ${ }^{15} \mathrm{~N}$ is preferentially taken up relative to ${ }^{14} \mathrm{~N}$ (Fig. 3B). The model systematically underestimated $\delta^{15} \mathrm{~N}_{\mathrm{PON}}$, particularly during the drawdown of $\left[\mathrm{NH}_{4}{ }^{+}\right]$.

\section{Chaetoceros debilis}

In the $\mathrm{N}$-sufficient phase ( 0 to $73 \mathrm{~h}$ ), $\mathrm{NH}_{4}{ }^{+}$was taken up first, followed by the simultaneous uptake of nitrate and urea (Fig. 4A). Unlike the 3 previous cultures, there were large fluctuations in $\delta^{15} \mathrm{~N}_{\text {PON }}$ during growth on $\mathrm{NH}_{4}{ }^{+}$(Fig. 4B), which were reproduced in a duplicate culture. It is not clear what produced those fluctuations, but it is to be noted that the cells of this culture tended to aggregate as biomass increased. It is thus possible that a microenvironment developed around the cells where the $\delta^{15} \mathrm{~N}$ of $\mathrm{NH}_{4}{ }^{+}$(and thus $\mathrm{NH}_{3}$ ) was quite different relative to ambient concentration. Diffusion of $\mathrm{NH}_{3}$ in and out of that microenvironment may have produced the fluctuations in $\delta^{15} \mathrm{~N}_{\mathrm{PON}}$ since the value of $\varepsilon$ for the equilibrium $\mathrm{NH}_{4}{ }^{+} / \mathrm{NH}_{3}$ is $20 \%$ (Hermes et al. 1985). The decrease in PON concentration at the stationary phase is presumably due to the cell aggregation which was quite extensive as cells progressively consumed all the $\mathrm{N}$ sources (Fig. 4B). This explanation would be consistent with the fact that $\delta^{15} \mathrm{~N}_{\mathrm{PON}}$ was similar to $\delta^{15} \mathrm{~N}_{\mathrm{mx}}$ (Table 2). The modeled $\delta^{15} \mathrm{~N}_{\text {PON }}$ gave a relatively good fit for the initial 0 to $52 \mathrm{~h}$ time period but did not reproduce the maximum at $1 \%$ and minimum at $-2 \%$ observed during the simultaneous uptake of nitrate and urea (52 to $64 \mathrm{~h}$ ). In the $\mathrm{N}$-resupply phase. $\mathrm{NH}_{4}{ }^{+}$was not taken up immedi- 

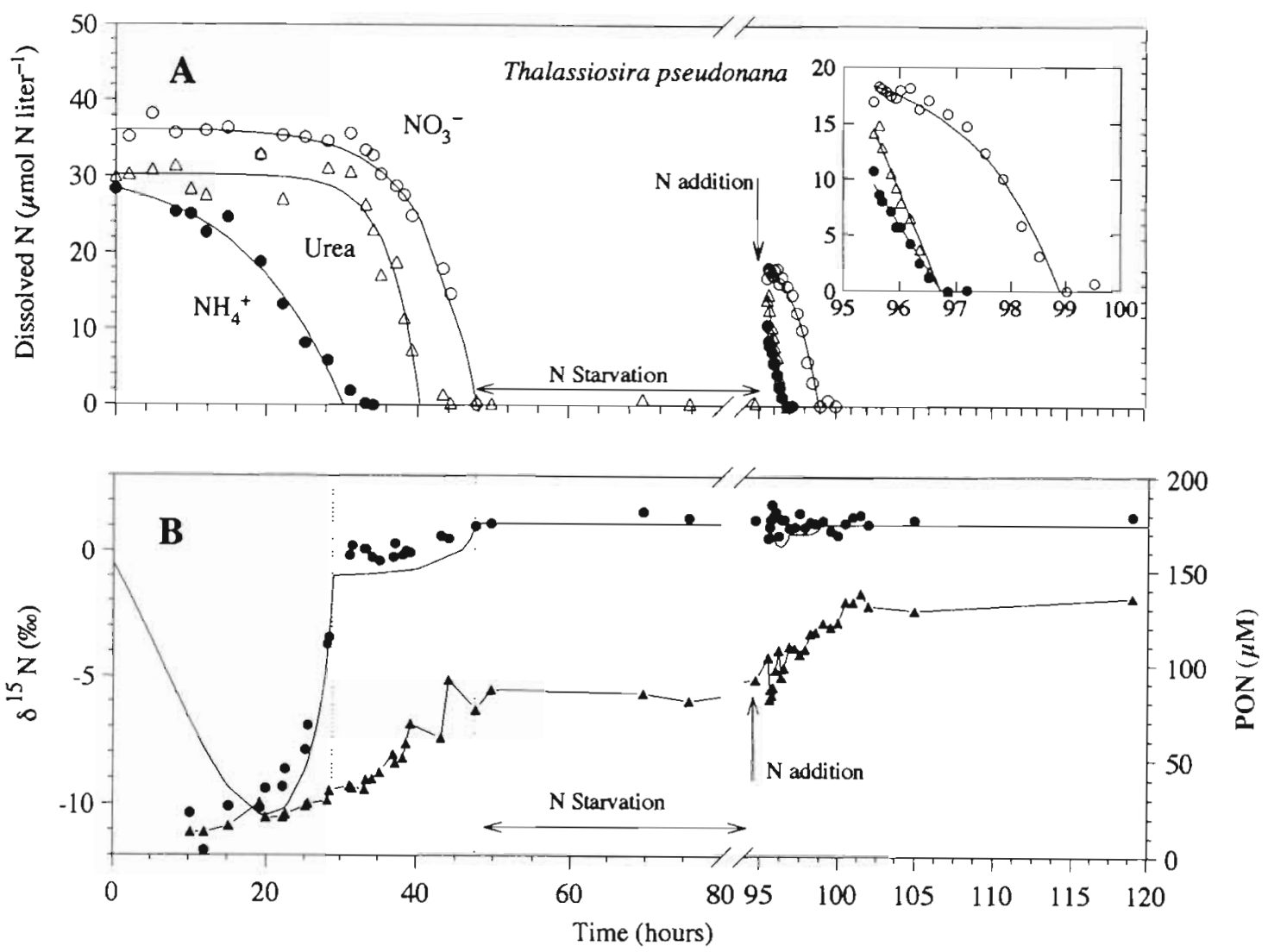

Fig. 3. Thalassiosira pseudonana. Growth on $\mathrm{NO}_{3}{ }^{-}, \mathrm{NH}_{4}{ }^{+}$and urea. (A) Time series of $\left[\mathrm{NO}_{3}{ }^{-}\right](\mathrm{O})$, $\left[\mathrm{NH}_{4}{ }^{+}\right](\bullet)$ and $[\mathrm{urea}](\Delta)$. The best fits for the concentrations are indicated by the solid lines. (B) Time series of measured PON $(\boldsymbol{\Delta})$ and $\delta^{15} N_{P O N}(\bullet)$. The $\delta^{15} N_{P O N}$ as predicted by the model is shown by the solid line. The 2 dotted lines represent times when $\left[\mathrm{NH}_{4}{ }^{+}\right]$and $\left[\mathrm{NO}_{3}{ }^{-}\right]$fits reached 0 , respectively

ately, unlike in all previous cultures (Fig. 4A). The model systematically underestimated the $\delta^{15} \mathrm{~N}_{\text {PON }}$, but most of all could not predict the 2 large maxima (Fig. 4B). A duplicate culture was analyzed and confirmed these features. The results for the duplicate cultures are summarized in Table 2.

\section{Sensitivity analysis}

\section{$\mathrm{N}$-sufficient conditions and coccolithophore cultures}

Changes in various variables were made to study their effect on the $\delta^{15} \mathrm{~N}_{\text {PON }}$ in $\mathrm{N}$-replete conditions. In this study, the value of $\varepsilon$ (urea) was taken as a constant of $0 \%$. For the coastal clone of Emiliania huxleyi, changes in the values of $\varepsilon\left(\mathrm{NH}_{4}\right), \varepsilon\left(\mathrm{NO}_{3}\right)$ and $P O N_{1}$ are shown in Fig. 5. Variations in the values of $\varepsilon\left(\mathrm{NH}_{4}\right)$ and $\mathrm{PON}_{\mathrm{i}}$ produced large changes in the $\delta^{15} \mathrm{~N}_{\mathrm{PON}}$ at low PON concentrations (Fig. 5A, B). Thus $\mathrm{PON}_{\mathrm{i}}$ is a critical variable in determining $\varepsilon\left(\mathrm{NH}_{4}\right)$ and, in this case, an underestimation of $\mathrm{PON}_{\mathrm{i}}$ by $1 \mu \mathrm{M}$ leads to an overesti- mation of $\varepsilon\left(\mathrm{NH}_{4}\right)$ of about $2 \%$. The value of $\varepsilon\left(\mathrm{NO}_{3}\right)$ that fits the data best is in the range of 4 to $6 \%$ (Fig. $5 \mathrm{C}$ ). similar to previously determined $\varepsilon$ for $E$. huxleyi and Thalassiosira pseudonana (Needoba 1997, Waser et al. 1998). For the open ocean clone of E. huxleyi, changes in $\varepsilon\left(\mathrm{NH}_{4}\right), \varepsilon\left(\mathrm{NO}_{3}\right)$, and $\mathrm{PON}_{1}$ were studied (Fig. 6). $\mathrm{PON}_{1}$ was again a critical variable, with a $2 \mu \mathrm{M}$ error on $\mathrm{PON}_{i}$ equivalent to a 1 to $1.5 \%$ change in $\varepsilon\left(\mathrm{NH}_{4}\right)$ (Fig, 6A, B). There were few data collected during the nitrate uptake phase, but $\varepsilon\left(\mathrm{NO}_{3}\right)$ was clearly larger than $2 \%$ and closer to $4-6 \%$ (Fig. $6 \mathrm{C}$ ) as in 2 of the triplicate cultures (Table 2).

\section{$\mathrm{N}$-sufficient conditions and diatom cultures}

For Thalassiosira pseudonana, the model predicted the data well for growth on $\mathrm{NH}_{4}{ }^{+}$for $\varepsilon\left(\mathrm{NH}_{4}\right)$ values of 18 to $20 \%$ (Fig. $7 \mathrm{~A}$ ). PON 1 had again a large effect on the response of the model during the initial growth on $\mathrm{NH}_{4}{ }^{+}$(Fig. 7B). Changes in the fit for $\left[\mathrm{NH}_{4}{ }^{+}\right]$were made. This is because the rapid change in $\delta^{15} \mathrm{~N}_{\text {PON }}$ 

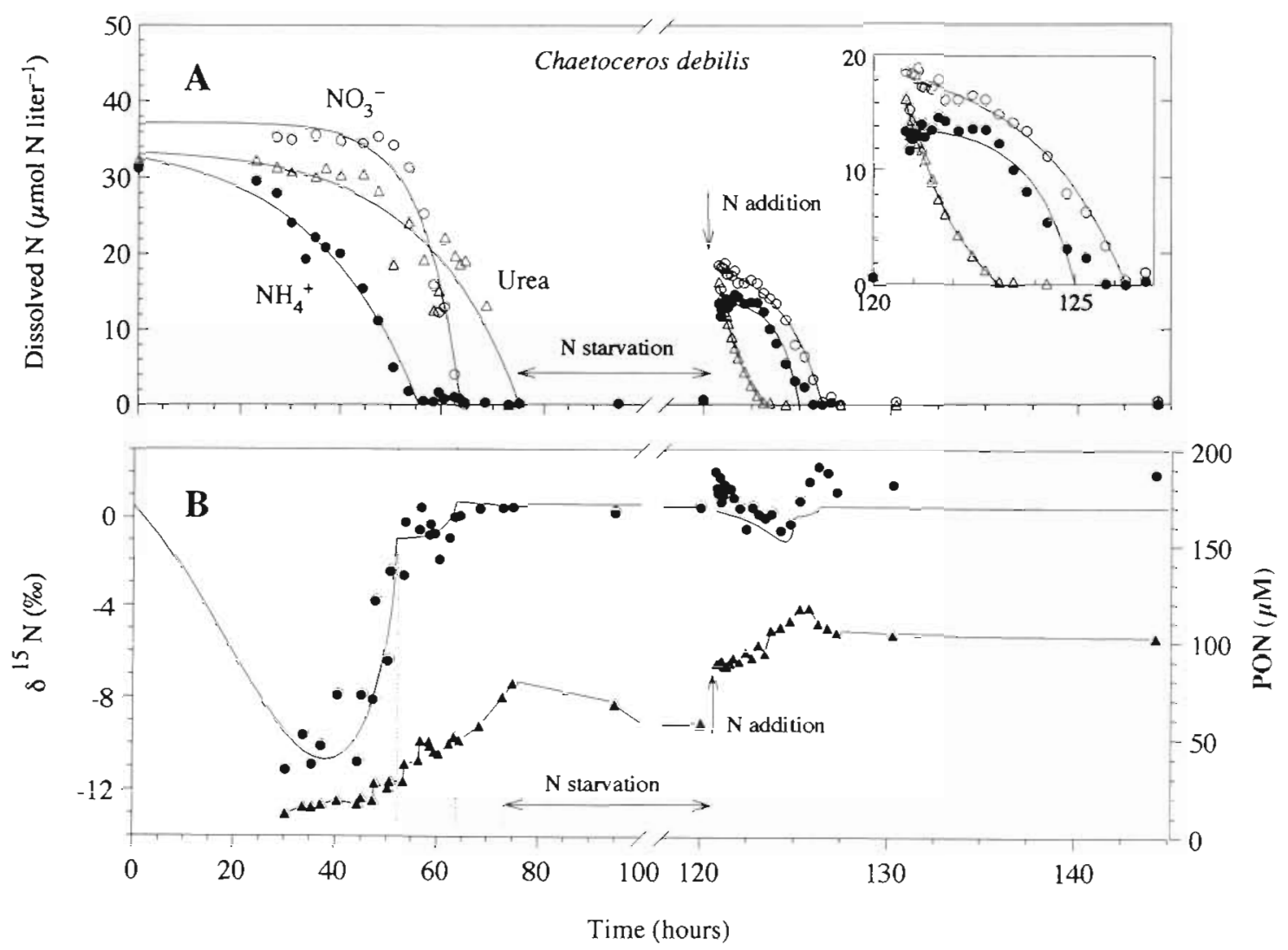

Fig. 4. Chaetoceros debilis. Growth on $\mathrm{NO}_{3}{ }^{-}, \mathrm{NH}_{4}{ }^{+}$and urea. (A) Time series of $\left[\mathrm{NO}_{3}{ }^{-}\right](0),\left[\mathrm{NH}_{4}{ }^{+}\right](\bullet)$ and [urea] $(\Delta)$. The best fits for the concentrations are indicated by the solid lines. (B) Time series of measured PON $(\Delta)$ and $\delta^{15} N_{\text {PON }}(\bullet)$. The 3 dotted lines indicate times when $\left[\mathrm{NH}_{4}{ }^{+}\right],\left[\mathrm{NO}_{3}{ }^{-}\right]$and [urea] fits reached 0 , respectively. The $\delta^{15} \mathrm{~N}_{\text {PON }}$ as predicted by the multiple $\mathrm{N}$ substrate uptake model is shown by the solid line

leading to the complete consumption of $\mathrm{NH}_{4}{ }^{+}$clearly depended on the fit for $\left[\mathrm{NH}_{4}^{+}\right]$. Thus, the time at which $\left[\mathrm{NH}_{4}{ }^{+}\right]$reaches 0 (i.e. T) was fixed to different values with the condition that it still gave a good $\left[\mathrm{NH}_{4}{ }^{+}\right]$fit (Fig. $7 \mathrm{C}$ ). A range of variables was examined in an attempt to account for the offset in the 30 to $95 \mathrm{~h}$ period. First, $\varepsilon\left(\mathrm{NO}_{3}\right)$ was decreased to a minimum value of $0 \%$ (Fig. 7D). Then, the $\delta^{15} \mathrm{~N}$ of the source nitrate was empirically increased to a maximum value of $4.4 \%$ instead of $3 \%$. This last modification allowed for the model to better fit the data at the stationary phase, but only slightly improved the fit in the 29 to $47 \mathrm{~h}$ time period (Fig. 7E). Lastly, changes in the $\delta^{15} \mathrm{~N}$ of $P O N_{i}$ were made since $\mathrm{PON}_{i}$ concentration was high in this culture (Table 2). These changes had a rather small effect on the fit for the 29 to $47 \mathrm{~h}$ time period, although higher $\delta^{15} \mathrm{~N}$ of $\mathrm{PON}_{1}$ tended to improve the fit (Fig. 7F). For Chaetoceros debilis, the values of $\varepsilon\left(\mathrm{NH}_{4}\right)$ which fitted the data were larger than for the previous cultures (Fig. 8A). Since $\mathrm{PON}_{\mathrm{i}}$ was relatively high in this culture and had a large effect on the fit (Fig 8B), its underestimation may have led to an overestimation of $\varepsilon\left(\mathrm{NH}_{4}\right)$.

\section{N-resupply phase}

A sensitivity study was made by varying $\varepsilon\left(\mathrm{NH}_{4}\right)$ from 0 to $20 \%$ or $25 \%$ in the case of Chaetoceros debilis. Other variables had too small an effect relative to the scatter in the data and were thus not investigated. Again, the base variables used in the model are given in Table 2. In contrast to the $\mathrm{N}$-sufficient phase, the model did not fit the data well in all 3 coastal clones (Fig 9). For the coastal clone of Emiliania huxleyi, the model predicted well the data during $\left[\mathrm{NO}_{3}{ }^{-}\right]$drawdown and at the stationary phase (Fig. 9A). However, none of the values of $\varepsilon\left(\mathrm{NH}_{4}\right)$ could fit the data during the simultaneous $\left[\mathrm{NH}_{4}{ }^{+}\right]$and [urea] drawdowns. Interestingly, the model predicted well the data for $E$. huxleyi (open ocean clone) for values of $\varepsilon\left(\mathrm{NH}_{4}\right)$ of $20 \%$ (Fig. 9B), which was similar in magnitude to the one derived in the N-sufficient phase. For Thalassiosira pseudonana, the model systematically underestimated the $\delta^{15} \mathrm{~N}_{\text {PON }}$ and again no value of $\varepsilon\left(\mathrm{NH}_{4}\right)$ could account for the high $\delta^{15} \mathrm{~N}_{\text {PON }}$ of about 1 to $1.8 \%$ during all three $\mathrm{N}$ uptakes (Fig. 9C). In the case of $C$. debilis, the $\delta^{15} \mathrm{~N}_{\text {pon }}$ values depart even more from the model 

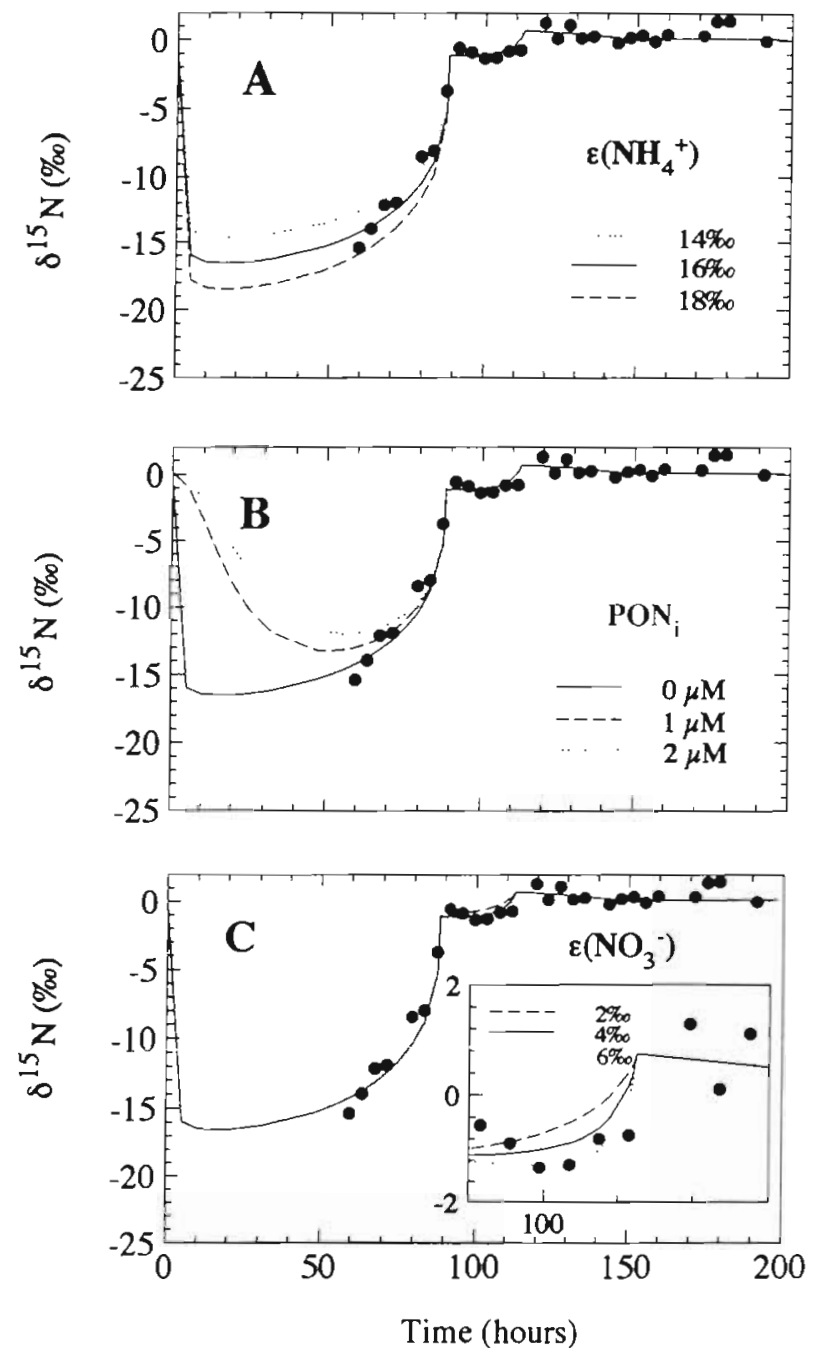

Fig. 5. Response of the model to changes in (A) $\varepsilon\left(\mathrm{NH}_{4}\right)$, (B) PON and (C) $\varepsilon\left(\mathrm{NO}_{3}\right)$ for Emiliania huxleyi (coastal clone) in $\mathrm{N}$-sufficient conditions. The solid lines represent the response of the model using the base values indicated in Table 2

and again no value of $\varepsilon\left(\mathrm{NH}_{4}\right)$ can eliminate the discrepancy (Fig. 9D).

\section{DISCUSSION}

This study has shown that in conditions of $\mathrm{N}$-sufficiency, the $\delta^{15} \mathrm{~N}_{\text {PON }}$ resulting from the growth of coccolithophores and diatoms in a medium containing nitrate, ammonium and urea could be relatively well predicted by the model (Figs. 1, 2, $3 \& 4$ ). The largest discrepancies between the modeled and observed $\delta^{15} \mathrm{~N}_{\text {PoN }}$ occurred during the simultaneous growth of the 2 diatoms on nitrate and urea (Figs. $3 \& 4$ ). Otherwise, knowledge of the values of $\varepsilon$ for growth on the individual $N$ sources allowed the variations in the
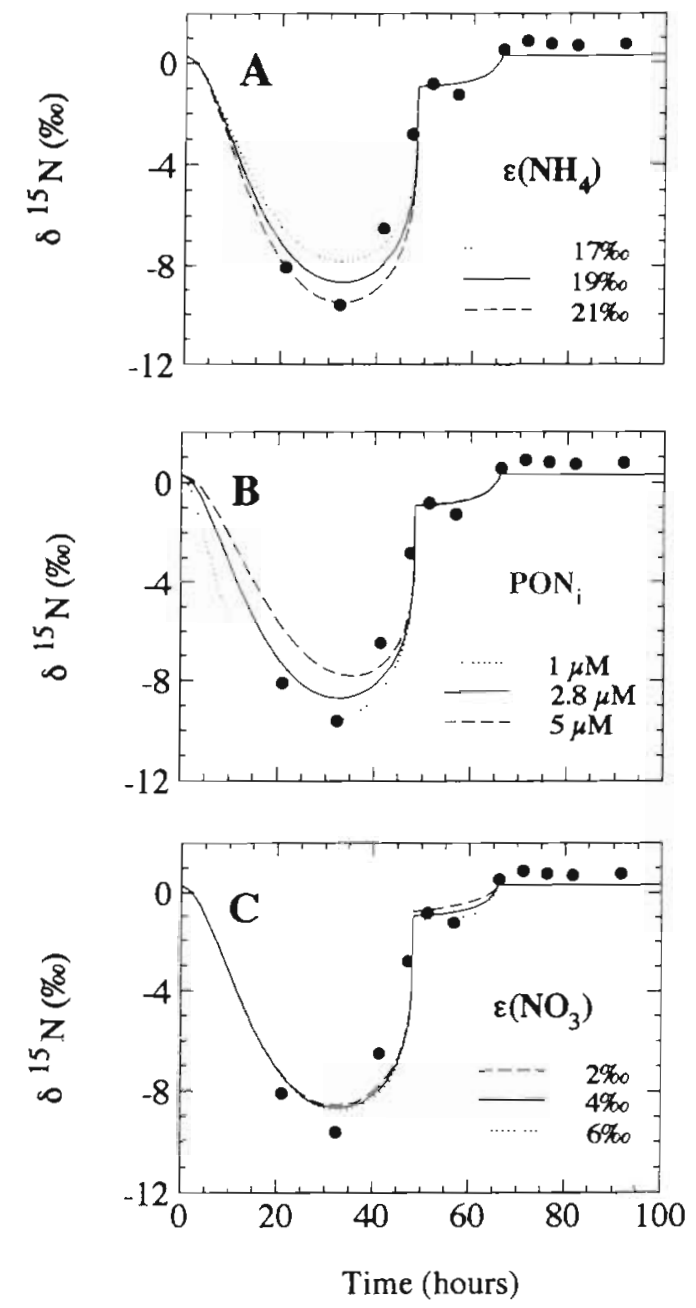

Fig. 6. Response of the model to changes in (A) $\varepsilon\left(\mathrm{NH}_{4}\right)$, (B) PON 1 and (C) $\varepsilon\left(\mathrm{NO}_{3}\right)$ for Emiliania huxleyi (open ocean clone) in $\mathrm{N}$-sufficient conditions

$\delta^{15} \mathrm{~N}_{\text {PON }}$ of coccolithophores to be predicted very well (Figs. $1 \& 2$ ). The $\varepsilon$ values that allowed the model to fit the data well were similar to those previously determined in similar culture conditions (Needoba 1997 , Waser et al. 1998). In $\mathrm{N}$-replete conditions, $\varepsilon\left(\mathrm{NO}_{3}\right)$ ranged from 4 to 5 "in for Emiliania huxleyi and Chaetoceros debilis (Table 2), similar to previous estimates of $3.9 \pm 0.3 \%$ for the open ocean clone of $E$. huxleyi (Needoba 1997), $3.0 \pm 0.5 \%$ for Chaetoceros simplex (Needoba 1997), $5.2 \pm 0.2 \%$ for Thalassiosira pseudonana (Waser et al. 1998) and $6.2 \pm 0.3 \%$ for Thalassiosira weissflogii (Needoba 1997). In addition, the lower $\left[\mathrm{NO}_{3}{ }^{-}\right]$of 32 to $40 \mu \mathrm{M}$ used in this study did not affect $\varepsilon\left(\mathrm{NO}_{3}\right)$ as found by other authors (Pennock et al. 1996).

Growth on $\mathrm{NH}_{4}{ }^{+}$in $\mathrm{N}$-replete conditions was accompanied by very large values of $\varepsilon\left(\mathrm{NH}_{4}\right)$ ranging from 16 to $25 \%$ (Table 2). The lower values of 16 to $20 \%$ (error 

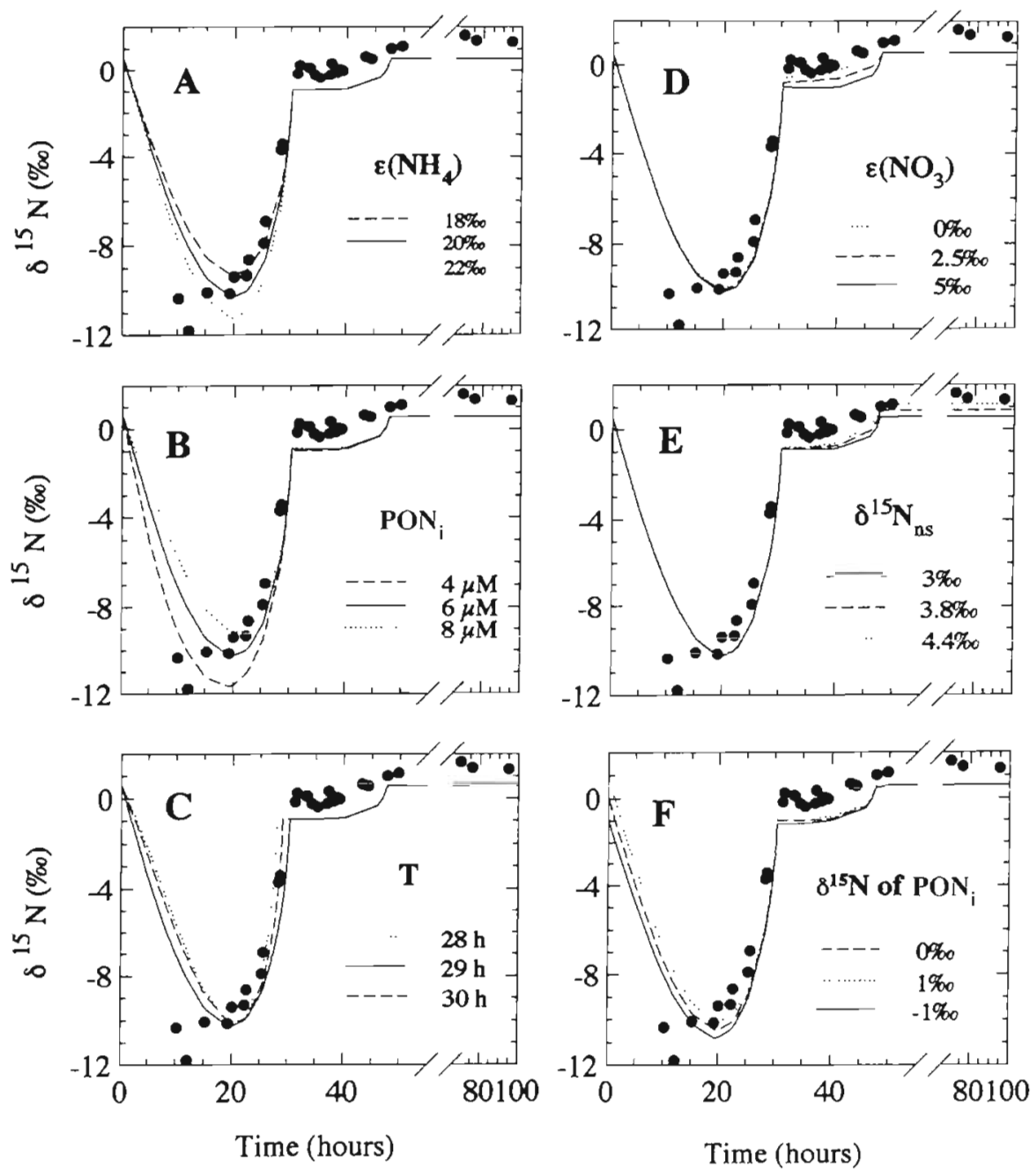

Fig. 7. Response of the model to changes in (A) $\varepsilon\left(\mathrm{NH}_{4}\right)$, (B) $P O N_{1}$, (C) $T_{1}$ (D) $\varepsilon\left(N O_{3}\right)$, (E) $\delta^{15} \mathrm{~N}_{\mathrm{ns}}$ and (F) $\delta^{15} \mathrm{~N}$ of $P O N$ for Thalassiosira pseudonana in $\mathrm{N}$-sufficient conditions

estimated at $2 \%$ ) are well within the range of previous estimates at similar $\left[\mathrm{NH}_{4}{ }^{+}\right]($Hoch et al. 1992) as well as those made at a higher $\left[\mathrm{NH}_{4}{ }^{+}\right]$of $200 \mu \mathrm{M}$ (Waser et al. 1998). Interestingly, the higher value of $25 \%$ for Chaetoceros debilis is very close to the estimate of $26 \%$ for Skeletonema costatum (Pennock et al, 1996), perhaps indicating that chain-forming cells discriminate more during $\mathrm{NH}_{4}{ }^{+}$incorporation. The mechanism of isotope fractionation for nitrate and ammonium incorporation is not understood at the present and thus the differences in estimates of $\varepsilon$ remain unclear. However, in the case of ammonium, it appears that culture conditions (e.g. $\left[\mathrm{NH}_{4}{ }^{+}\right]$, stirring, bubbling, $\mathrm{pH}$ and amount of inoculum) could have a greater effect on $\varepsilon$ relative to nitrate because of the possibility of gas exchange of $\mathrm{NH}_{3}$ at higher $\mathrm{pH}$ (Waser et al. 1998) and diffusion of $\mathrm{NH}_{3}$ in and out of the cells (Hoch et al. 1992).
This study provides a potential explanation for field estimates of $\varepsilon\left(\mathrm{NH}_{4}\right)$ derived from a eutrophic estuary and bay (Cifuentes et al. 1989, Montoya et al. 1991) being lower than the estimates derived from culture experiments. In the case of Emiliania huxleyi (open ocean clone), we have found that the apparent discrimination was initially lower than for growth on $\mathrm{NH}_{4}{ }^{+}$ alone. The model clearly showed that it was due to simultaneous growth on urea and $\mathrm{NH}_{4}{ }_{4}$, with values of $\varepsilon$ of $17 \%$ for $\mathrm{NH}_{4}{ }^{+}$and $0 \%$ for urea. In the field, urea and $\mathrm{NH}_{4}{ }^{+}$are often present at similar concentrations (Harrison 1992). If these two $N$ sources were taken up simultaneously by phytoplankton, then the changes in $\delta^{15} N_{\text {PON }}$ would be smaller in magnitude relative to growth on $\mathrm{NH}_{4}{ }^{+}$alone. Also, the changes in the $\delta^{15} \mathrm{~N}$ of $\mathrm{NH}_{4}{ }^{+}$might be smaller if urea and $\mathrm{NH}_{4}{ }^{+}$uptake are coupled as suggested by Price \& Harrison (1988). If $\mathrm{NH}_{3}$ was excreted during urea uptake in the ocean, 

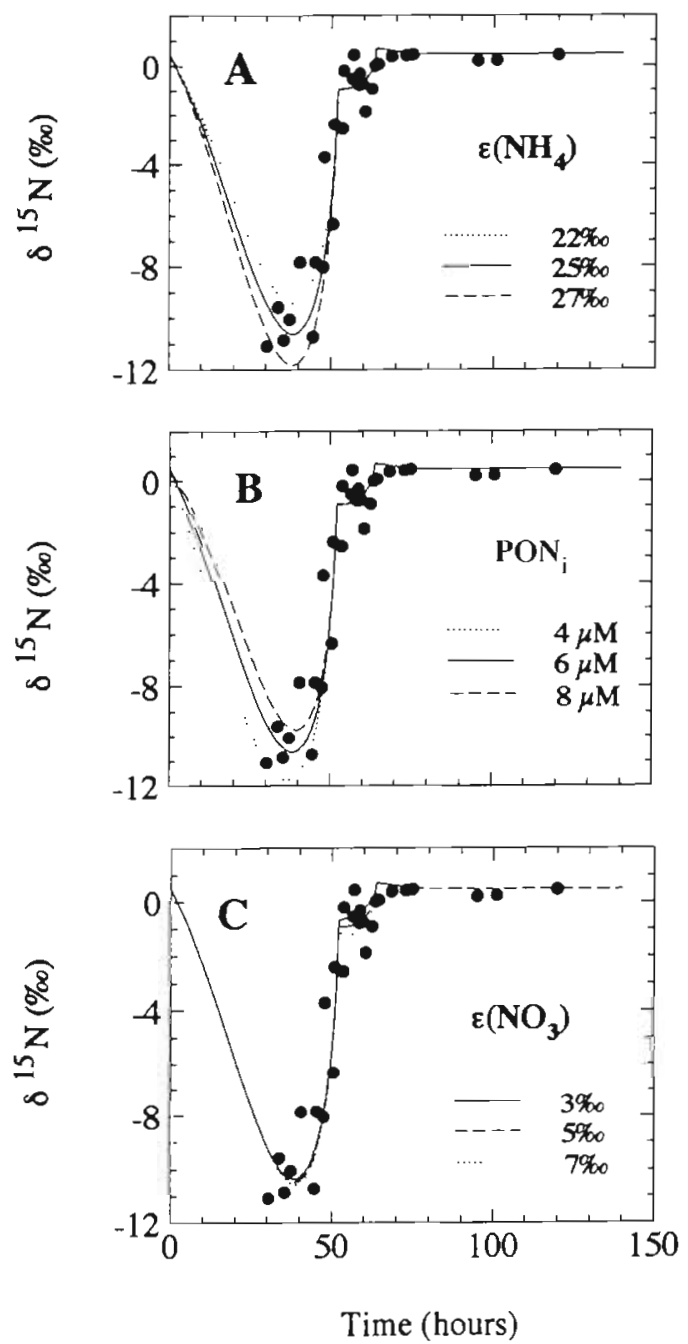

Fig. 8. Response of the model to changes in (A) $\varepsilon\left(N_{4}\right)_{4}$, (B) PON, and (C) $\varepsilon\left(\mathrm{NO}_{3}\right)$ for Chaetoceros debilis in N-sufficient conditions

then the $\delta^{15} \mathrm{~N}$ of ambient $\mathrm{NH}_{4}^{+}$would reflect the discrimination that occurs during both urea and $\mathrm{NH}_{4}{ }^{+}$ uptake. This would result in a lower field estimate of $\varepsilon\left(\mathrm{NH}_{4}\right)$. While this process may not be of importance in $\mathrm{N}$-depleted regimes because $\mathrm{N}$ efflux may be very small, it may be important to consider in eutrophic environments such as the Delaware Estuary and the Chesapeake Bay.

This study also suggests that the simultaneous uptake of $\mathrm{NO}_{3}{ }^{-}$and $\mathrm{NH}_{4}{ }^{+}$which prevails in many environments (Harrison 1992) may substantially affect the $\delta^{15} \mathrm{~N}_{\text {PON }}$. During simultaneous $\mathrm{NO}_{3}{ }^{-}$and $\mathrm{NH}_{4}{ }^{+}$depletion, large variations in $\delta^{15} \mathrm{~N}_{\mathrm{PON}}$ may occur depending on the uptake of $\mathrm{NH}_{4}{ }^{+}$relative to that of $\mathrm{NO}_{3}{ }^{-}$. Because $\varepsilon\left(\mathrm{NH}_{4}\right)$ is so large, a small $\mathrm{NH}_{4}{ }^{+}$uptake could produce a relatively large change in $\delta^{15} \mathrm{~N}_{\text {pon }}$. This may account for observations previously made of a relatively large variation in $\delta^{15} \mathrm{~N}_{\text {PON }}$ when both $\mathrm{N}$ sources were present (Nakatsuka et al. 1992).

This study has shown that the $\mathrm{N}$ availability and the physiological state of phytoplankton have a large impact on the $\delta^{15} \mathrm{~N}_{\text {PoN }}$. Following $\mathrm{N}$-resupply, we observed a reverse discrimination (indicated by the positive $\Delta$ values) for the 2 coastal diatoms and the coastal clone of a coccolithophore (Fig. 9A, C, D). These observations suggest that excretion of a ${ }^{15} \mathrm{~N}$ depleted compound into the medium may have occurred. Several N compounds may have been excreted. Urea incorporation is known to produce excretory $\mathrm{NH}_{3}$ or $\mathrm{NH}_{4}{ }^{+}$and perhaps amino acids as well (Price \& Harrison 1988). Amino acids may become enriched in ${ }^{15} \mathrm{~N}$ if they accumulate in the cell prior to being excreted (Macko et al. 1987). A compound that accumulates implies that the enzyme involved in its transformation is rate limiting. Since, in most of the cases, intrinsic isotope fractionation ( $\beta$ ) associated with enzymes is normal (i.e. the product is ${ }^{15} \mathrm{~N}$-depleted and the substrate ${ }^{15} \mathrm{~N}$-enriched), accumulating 'substrates' will tend to be ${ }^{15} \mathrm{~N}$-enriched. On the other hand, $\mathrm{NH}_{3}$ diffusion across the membrane may have an $\varepsilon$ as large as $39 \%$ (Hermes et al. 1985). This process could make excretory $\mathrm{NH}_{3}$ very ${ }^{15} \mathrm{~N}$-depleted. Perhaps due to the high rates of both urea and ammonium assimilation, particularly in the cases of Emiliania huxleyi (coastal clone) and Thalassiosira pseudonana, $\mathrm{NH}_{3}$ concentration inside the cells was reaching levels high enough to enhance its effiux. In the case of Chaetoceros debilis, the relatively large initial increase in $\left[\mathrm{NH}_{4}{ }^{+}\right]$in the $\mathrm{N}$ resupply phase would be consistent with that hypothesis (Fig. 4A). Whether isotopically light amino acids or $\mathrm{NH}_{3}$ (due to diffusion of isotopically light $\mathrm{NH}_{3}$ out of the celli is excreted is not known.

Finally, the changes in $\delta^{15} \mathrm{~N}_{\text {poN }}$ found in this study are contrary to expectations of lower $\varepsilon$ in $N$-limiting conditions. We had anticipated that $\varepsilon$ would decrease or be close to zero following $\mathrm{N}$-resupply to $\mathrm{N}$-starved phytoplankton as efflux of $\mathrm{N}$ out of the cell might decrease under $\mathrm{N}$-depleted conditions. This is clearly not what was observed. Instead, evidence for a change in the mechanism of isotope fractionation was observed in the case of 3 coastal species of phytoplankton. In contrast, in the case of Emiliania huxleyi isolated from the Subarctic Pacific Ocean, we found no evidence for a change in mechanism with $\mathrm{N}$ availability and thus physiological state. This latter result suggests that this species is able to quickly recover from $\mathrm{N}$-starvation. In the natural environment, this species would be able to rapidly take up new and regenerated forms of nitrogen appearing in the euphotic zone as a result of episodic events and respond with a similar isotope discrimination as in N-replete conditions. More studies will be needed to determine whether the dif- 
ference observed between the 3 coastal clones and the open ocean clone will apply to other species as well.

In summary, this is the first study showing the impact of $\mathrm{N}$ availability and hence physiological state on $\mathrm{N}$ isotope fractionation by phytoplankton. It is also the first time that the effect of growth on mixed $\mathrm{N}$ sources is evaluated. In particular, simultaneous uptake of two $\mathrm{N}$ sources was shown to have a different impact on $\delta^{15} \mathrm{~N}_{\text {PON }}$ depending on $\mathrm{N}$ forms and algae. These findings have important implications and point out the complexity of interpreting changes in $8^{15} \mathrm{~N}_{\text {PON }}$ in the
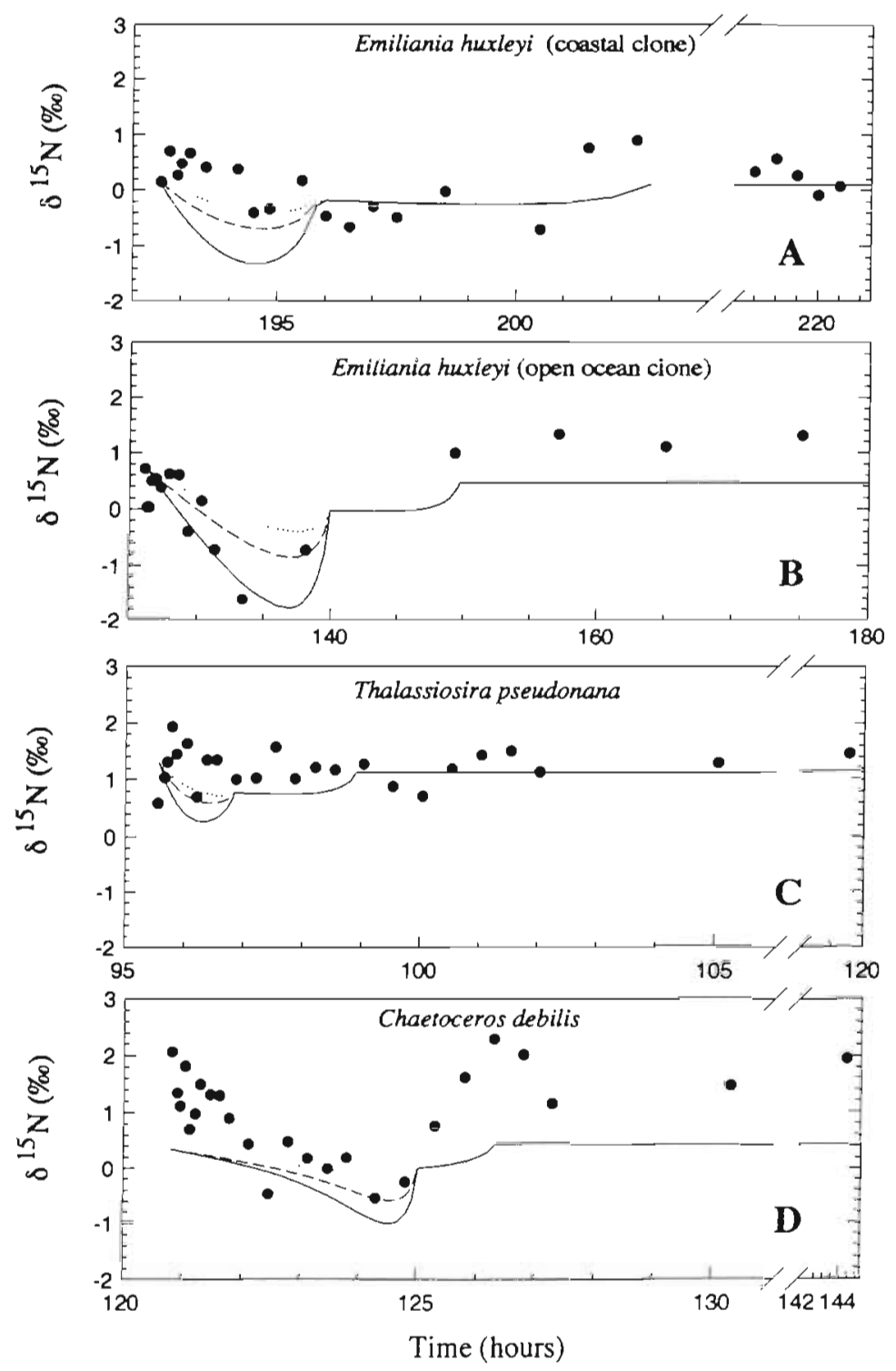

Fig. 9. Response of the model to changes in $\varepsilon\left(\mathrm{NH}_{4}\right)$ in the $\mathrm{N}$-resupply phase $\varepsilon\left(\mathrm{NH}_{, ;}\right)$values are $20 \%$ (solid line), $10 \%$ (dashed line) and $5 \%$ (dotted line) for Emiliania huxleyi and Thalassiosira pseudonana, and 25\% (solid line), 15\% (dashed line) and 5\% (dotted line) for Chaetoceros debilis. The solid lines represent the response of the model using the base variables indicated in Table 2 ocean surface. We suggest that in addition to knowledge of $\varepsilon$ for each individual $N$ source, it is important to understand interactions between nitrogenous nutrients, $\mathrm{N}$ availability conditions, species composition and the response of each species in the ocean surface.

Acknowledgements. Funding for this research was provided by a Collaborative Project Grant from the Natural Sciences and Engineering Research Council (NSERC) of Canada and by the National Natural Sciences Foundation of China (No. 49676303 ) awarded to Z. Yu. We thank Bente Nielsen for running the samples on the mass spectrometer. We also thank Sharif Aktary for the fruitful discussions on the mathematical formulations. The authors are grateful to 4 reviewers who made constructive and very helpful comments.

\section{LITERATURE CITED}

Altabet MA (1988) Variations in nitrogen isotopic composition between sinking and suspended particles: implications for nitrogen cycling and particle tranformation in the open ocean. Deep Sea Res 35:535-554

Altabet MA, Deuser WG, Honjo S, Steinen C (1991) Seasonal and depth-related changes in the source of sinking particles in the North Atlantic. Nature 354:136-139

Cifuentes LA, Fogel ML, Pennock JR, Sharp JH (1989) Biogeochemical factors that influence the stable nitrogen isotope ratio of dissolved ammonium in the Delaware Estuary. Geochim Cosmochum Acta 53:2713-2721

Dortch Q. Conway HL (1984) Interactions between nitrate and ammonium uptake: variation with growth rate, nitrogen source and species. Mar Biol 79:151-164

Dortch Q, Thompson PA, Harrison PJ (1991) Shortterm interaction between nitrate and ammonium uptake in Thalassiosira pseudonana: effect of preconditioning nitrogen source and growth rate. Mar Biol 110:183-193

Evans RD, Bloom AJ, Sukrapanna SS, Ehleringer JR (1996) Nitrogen isotope composition of tomato (Lycopersion esculentum Mill. cv. T-5) grown under ammonium or nitrate nutrition. Plant Cell Environ 19:1317-1323

Fogel ML, Cifuentes LA (1993) Isotope fractionation during primary production. In: Engel $\mathrm{MH}_{\text {, }}$ Macko SA (eds) Organic geochemistry. Plenum Press, New York, p 73-98

Handley LL, Raven JA. (1992) The use of natural abundance of nitrogen isotopes in plant physiology and ecology. Plant Cell Environ 15:965-985

Harrison PJ, Waters RE, Taylor FJR (1980) A broad spectrum artificial seawater medium for coastal and open ocean phytoplankton. J Phycol $16: 28-35$

Harrison WG (1992) Regeneration of nutrients. In: Falkowski PG, Woodhead AD (eds) Primary productivity and biogeochemical cycles in the sea. Plenum Press, New York, p 385-407

Hermes JD, Weiss PM, Cleland WW (1985) Use of nitrogen-15 and deuterium isotope effects to determine the chemical mechanism of phenyl- 
alanine ammonia-lyase. Biochemistry 24:2959-2967

Hoch MP, Fogel ML, Kirchman DL (1992) Isotope fractionation associated with ammonium uptake by a marine bacterium. Limnol Oceanogr 37:1447-1459

Horrigan SG, Montoya JP, Nevins JL, McCarthy JJ (1990) Natural isotopic composition of dissolved inorganic nitrogen in the Chesapeake Bay. Estuar Coastal Shelf Sci 30: $393-410$

Jones MN (1984) Nitrate reduction by shaking with cadmium, alternative to cadmium columns. Water Res 18:643-646

Macko SA, Fogel ML. Hare PE, Hoering TC (1987) Isotopic fractionation of nitrogen and carbon in the synthesis of amino acids by microorganisms. Chem Geol 65:79-92

Mariotti A, Germon JC, Hubert $P$, Kaiser $P$, Letolle R, Tardieux A, Tardieux $P$ (1981) Experimental determination of nitrogen kinetıc isotope fractionation: some princ1ples; illustration for the denitrification and nitrification processes. Plant Soil 62:413-430

Mariotti A, Mariotti F, Champigny M, Amarger N, Moyse A (1982) Nitrogen isotope fractionation associated with nitrate reductase activity and uptake of $\mathrm{NO}_{3}$ by Pearl Millet. Plant Physiol 69:880-884

McCarthy JJ, Goldman JC (1979) Nitrogenous nutrition of marine phytoplankton in nutrient-depleted waters. Science 203:670-672

Montoya JP, Horrigan SG, McCarthy JJ (1991) Rapid, storminduced changes in the natural abundance of ${ }^{15} \mathrm{~N}$ in a planktonic ecosystem, Chesapeake Bay, USA. Geochim Cosmochim Acta 55:3627-3638

Montoya JP, McCarthy JJ (1995) Isotopic fractionation during nitrate uptake by phytoplankton grown in continuous culture. J Plankion Res 17:439-464

Nakatsuka T, Handa N, Wada E, Wong CS (1992) The dynamic changes of stable isotopic ratios of carbon and nitrogen in suspended and sedimented particulate organic matter during a phytoplankton bloom. J Mar Res $50: 267-296$

Needoba J (1997) Nitrogen isotope fractionation by four groups of phytoplankton grown on nitrate. BSc dissertation, University of British Columbia, Vancouver

Editorial responsibility: Otto Kinne (Editor), Oldendorf/Luhe, Germany
Pennock JR, Velinsky DJ, Ludlam JM, Sharp JH (1996) Isotopic fractionation of ammonium and nitrate during uptake by Skeletonema costatum: implications for $\delta^{15} \mathrm{~N}$ dynamics under bloom conditions. Limnol Oceanogr 41 $451-459$

Price NM, Harrison PJ (1987) Comparison of methods for the analysis of dissolved urea in seawater Mar Biol 94: 307-317

Price NM, Harrison PJ (1988) Uptake of urea C and $N$ by the coastal marine diatom Thalassiosira pseudonana. Limnol Oceanogr 33:528-537

Sigman DM, McCorckle DC. Francois R, Donaghue J, Altabet MA, Michener R, Fry B (1996) A new method for the nitrogen isotopic analysis of oceanic nitrate and first results from the Southern Ocean. 1996 Ocean Science Meeting, San Diego. EOS (Trans Am Geophys Un) 76:143

Slawyk G, Maclsaac JJ (1972) Comparison of two automated ammonium methods in a region of coastal upwelling. Deep Sea Res 19:521-524

Villareal TA, Altabet MA, Culver-Rymsza K (1993) Nitrogen transport by vertically migrating diatom mats in the North Pacific Ocean. Nature 363:709-712

Voss $\mathrm{M}$, Altabet MA, Bodungen Bv (1996) $\delta^{15} \mathrm{~N}$ in sedimenting particles as indicator of euphotic-zone processes. Deep Sea Res 43:33-47

Wada E (1980) Nitrogen isotope fractionation and its significance in biogeochemical processes occurring in marine environments. In: Goldberg ED, Horibe Y, Saruhashi K (eds) Isotope marine chemistry. Uchida-Rokakuho, Tokyo, p 375-398

Wada E, Hattori A (1978) Nitrogen isotope effects in the assimilation of inorganic nitrogenous compounds by marine diatoms. Geomicrobiol J 1:85-101

Waser NAD, Turpin DH, Harrison PJ, Nielsen B, Calvert SE (1998) Nitrogen isotope fractionation during the uptake and assimilation of nitrate, nitrite, ammonium and urea by a marine diatom. Limnol Oceanogr 43:215-224

Wu J, Calvert SE, Wong CS $(1997){ }^{15} \mathrm{~N} /{ }^{14} \mathrm{~N}$ isotope ratios in the subarctic northeast Pacific ecosystem: nitrate utilization and trophic structure. Deep Sea Res 44:287-314

Submitted: December 15, 1997; Accepted: May 26, 1998

Proofs received from author(s): July 20,1998 